\title{
АНАЛИЗ ВОДНЫХ РАСТВОРОВ ПРИРОДНЫХ ГЛИКОЗИДОВ В-AМИРИНА - MUKOROSSI И QUILLAJA SAPONARIA МЕТОДОМ ТОНКОСЛОЙНОЙ ХРОМАТОГРАФИИ
}

Мироненко Н.В., Калмыкова А.С., Смусева С.О., Селеменев В.Ф. Воронежский государственный университет svetlana_smuseva@mail.ru

DOI: 10.26902/ASFE-11_174

Возрастающее с каждым годом число синтетических препаратов не снижает перспективу использования природных соединений. Благодаря широкому спектру биологической активности (адаптогенное, антиоксидантное, противомикробное, диуретическое, гемолитическое, гипогликемическое и др. действия) лидирующее положение среди подобных веществ занимают тритерпеновые сапонины [1-2].

Наиболее приемлемыми для анализа как сапонинов, так и их агликонов являются хроматографические методы, позволяющие не только отделить сапонины от сопутствующих продуктов в процессе их получения, но и разделить их на индивидуальные близкие по структуре соединения. Несмотря на высокую эффективность ВЭЖХ в химическом анализе высокомолекулярных веществ остаются задачи, связанные с простым и оперативным контролем их присутствия и в этом случае наиболее приемлемым является метод тонкослойной хроматографии. Целью настоящей работы являлась разработка способа идентификации сапонинов Mukorossi и Quillaja Saponaria методом тонкослойной хроматографии.

В ходе проведенных исследований по выбору оптимальных параметров хроматографирования были установлены: состав подвижной фазы, обеспечивающий оптимальное разделение индивидуальных тритерпеновых сапонинов, детектирующий реагент. Получаемые хроматограммы обрабатывались программой Денситометр. При анализе сапонинов Quillaja Saponaria рекомендовано использование подвижной фазы бутанол-этаноламмиак в соотношении 7:2:5. При исследовании сапонинов Mukorossi рекомендуется использование подвижной фазы н-бутанол-вода-уксусная кислота в соотношении 4:5:1. Выбранные составы позволяют контролировать процесс полноты извлечения сапонинов из растительного сырья и оптимизировать методику их гидролитического расщепления в условиях экспрессного анализа. Рассчитаны параметры хроматографического разделения: высота и число теоретических тарелок, полярность подвижных фаз по Снайдеру, селективность разделения. В качестве детектирующих реагентов, обладающих высокой чувствительностью к исследуемым соединения, рекомендован спиртовой раствор фосфорно-молибденовой кислоты. В качестве реагента, селективно окрашивающего зоны сапонинов и их агликона, был выбран $0,2 \%$ раствор пара-оксибензальдегида в $1 \mathrm{M} \mathrm{H}_{2} \mathrm{SO}_{4}$.

Полученные результаты и литературные данные позволили идентифицировать структуры индивидуальных соединений сапонинов и обосновать механизм их удерживания в неподвижном слое сорбента.

Работа выполнена при поддержке Министерства науки и высшего образования РФ в рамках государственного задания ВУЗам в сфере научной деятельности на 2020-2022 годы, проект № FZGU-2020-0044.

\section{Список литературы}

1. Vincken J.-P., Heng L., A. de Groot, Gruppen H. // Phytochemistry. 2007. №68. P.275-297.

2. Rodríguez-Díaza M., Delportea C., Cartagenaa C., Casselsb B. K. // Journal of farmacy and farmacology. 2011. №63. P.718-724. 